\title{
COMMENTS
}

\section{Curing Cancerphobia Phobia: Reasonableness Redefined}

\author{
Glen Donath $\dagger$
}

As early as 1912, cancerphobia has provided a successful theory of recovery for plaintiffs. ${ }^{1}$ Although a smattering of cancerphobia cases appeared in the following decades, ${ }^{2}$ cancerphobia actions were relatively uncommon until they appeared in large numbers in the toxic tort litigations of the $1980 \mathrm{~s}^{3}$ In its modern awakening, cancerphobia has arisen primarily from three distinct classes of cases: medical malpractice, DES, and asbestosis. ${ }^{4}$

In early cases, cancerphobia was analyzed as a subclass of nosophobia, the general fear of diseases. Damages for nosophobia

† B.A. 1992, Yale University; J.D. Candidate 1996, The University of Chicago.

1 See Alley $v$ Charlotte Pipe \& Foundry Co., 159 NC 327, 74 SE 885, 886 (1912). This Comment focuses solely on the negligent infliction of emotional distress in cancerphobia actions and takes no position on the appropriate standards for evaluating claims of intentional infliction.

2 See, for example, Ferrara $v$ Galluchio, 5 NY2d 16, 176 NYS2d 996, 152 NE2d 249 (1958).

${ }^{3}$ See, for example, Devlin v Johns-Manville Corp., 202 NJ Super 556, 495 A2d 495 (1985); Herber v Johns-Manville Corp., 785 F2d 79 (3d Cir 1986); Potter v Firestone Tire \& Rubber Co., 6 Cal 4th 965, 25 Cal Rptr 2d 550 (1993). See also E. Donald Elliott, The Future of Toxic Torts: Of Chemophobia, Risk as a Compensable Injury and Hybrid Compensation Systems, 25 Houston L Rev 781, 785 (1988) (suggesting that widespread press coverage of toxic torts stimulated public fear of cancer).

4 Fournier J. Gale III and James L. Goyer III, Recovery for Cancerphobia and Increased Risk of Cancer, 35 Defense L J 443, 450 (1986). Gale and Goyer also make a useful distinction between cancerphobia as a general anxiety of developing cancer and cancerphobia as a mental illness involving a fear of cancer in the absence of any objective danger. Id at 444-45. See also Potter, $25 \mathrm{Cal}$ Rptr 2d at 559. Although this Comment generally uses the term "cancerphobia" to mean a fear of cancer, it will refer to the mental illness cancerphobia when discussing the physical manifestation requirement. 
were traditionally considered a subclass of emotional distress damages, and cancerphobia was considered a garden-variety nosophobia action or "just a subspecies of mental anguish." Claims based on other forms of nosophobia have become more common as of late; for example, cases have been brought based on a fear of contracting AIDS $^{6}$ and a fear of becoming epileptic. ${ }^{7}$

In its modern form, however, cancerphobia is replete with complexities that set it apart from both traditional emotional distress claims and more circumscribed nosophobia actions. Unlike most diseases, it is medically unclear what causes most forms of cancer. Moreover, with increasing technological sophistication, it is likely that more potential carcinogens will be detected, spawning correlative fears of contracting cancer due to exposures to these substances. As a result, the fear of cancer "is an increasing burden because suspicion of links to cancer grows with the ability to measure minute substances. ${ }^{n 8}$ Despite technological advances, however,

a person's likelihood of developing cancer as a result of a toxic exposure is difficult to predict because many forms of cancer are characterized by long latency periods (anywhere from 20 to 30 years), and presentation is dependent upon the interrelation of myriad factors. ${ }^{9}$

Thus, it is difficult to gauge the relative reasonableness of fear of developing cancer from exposure to a particular chemical solution against, for example, fear of hepatitis after exposure to the virus. As the court in Alley $v$ Charlotte Pipe \& Foundry Co. noted, fear of cancer "must necessarily have a most depressing effect . . . [be-

5 Comment, Cancerphobia: Should Texas Courts Recognize This Tort Claim?, 29 Houston L Rev 219, 220-21 (1992). See also Hennessy $v$ Commonwealth Edison Co., $764 \mathrm{~F}$ Supp 495, 504 (N D $\mathrm{nl}$ 1991) ("Although often treated as [a] distinct doctrinal category, fear-of-cancer claims effectively comprise a particular subset of emotional distress claims in general.").

6 The Supreme Court recently denied certiorari in a case where a train conductor who feared AIDS, but was not HIV-positive, received a large damage award. Long Island Railroad Co. $v$ Marchica, 1995 US LEXIS 128, *1.

7 For a list of cases in which courts have allowed plaintiffs recovery for fear of developing a future disease due to the defendant's negligence, see Gale and Goyer, 35 Defense $\mathrm{L} J$ at 449-50 (cited in note 4) (noting that courts have allowed recovery for fear of hydrophobia induced by a bite from defendant's dog, fear of consequences from swallowing a needle in a cake, fear of future epilepsy after an automobile accident, fear of future disability after being thrown from a car, and fear of consequences of injury to a breast bone).

8 Crossing Delaney, Wall St J A14 (Oct 24, 1994).

9 Potter, 25 Cal Rptr $2 d$ at 560. 
cause l]ike the sword of Damocles, [the plaintiff] knows not when it will fall."10 Moreover, fear of cancer is a serious affliction; for instance, after a discovery that wood model workers are at a relatively high risk of contracting colon and rectal cancer, the workers ingested more alcohol and a psychologist expected more ulcers, drinking, and spousal abuse. ${ }^{11}$

Cancerphobia actions are sufficiently distinct that adjudicating them under the usual requirements for emotional distress damages makes little sense. Furthermore, the increasing frequency of cancerphobia suits and their potential for virtually unlimited liability necessitate a clear analytic framework for their evaluation. However, the increased frequency of cancerphobia suits has propagated a rather confused jurisprudence. In standard emotional distress actions, courts usually require a physical injury, either causing or resulting from the distress, as a condition precedent to recovery. ${ }^{12}$ Some courts have simply applied the standard physical injury requirement to cancerphobia suits. However, there has been a trend in some courts to discard the physical injury/manifestation-of-the-distress requirement and to require instead proof of the seriousness of the distress. ${ }^{13}$ This Comment will discuss and critique the various standards that courts have followed in adjudicating cancerphobia claims and will propose that courts abandon the physical injury/manifestation requirement in favor of an objective "substantial probability" test. This test would screen out meritless cases without being unduly restrictive, in contrast to tests such as the more-likely-than-not approach adopted by the Supreme Court of Califcrnia in Potter $v$ Firestone Tire \& Rubber Co. ${ }^{14}$ The Potter approach, this Comment will argue, helps more in drawing the distinction between recovery for increased probability of contracting cancer and recovery for fear of cancer than in deciding cancerphobia cases. Part I briefly discusses the distinction between increased risk of cancer

10159 NC 327,74 SE 885,886 (1912).

"See Terry Morehead Dworkin, Fear of Disease and Delayed Manifestation Injuries: A Solution or a Pandora's Box?, 53 Fordham L Rev 527, 565 (1984). Dworkin also discusses other possible effects of fear of cancer, such as "mild depression to severe psychosis ... stress, outbursts of rage and hostility, [and] loss of sleep." Id.

i2 See, for example, Payton v Abbott Labs, 386 Mass 540, 437 NE2d 171, 176 (1982). The court stated that the requirement of physical harm in emotional distress actions serves three functions: screening out insignificant claims, avoiding fraudulent claims, and protecting nonintentional defendants from liability for "purely mental disturbance[s]." Id at 178-79.

${ }_{13}$ See Dworkin, 53 Fordham L Rev at 532.

146 Cal 4th 965, 25 Cal Rptr 2d 550, 571 (1993). 
and cancerphobia. Part II discusses and critiques the various standards that courts have developed to evaluate cancerphobia claims. Part III proposes redefining reasonableness through adoption of a standard of substantial probability for the adjudication of cancerphobia claims.

\section{DeFINING THE ScOPE OF CANCERPHOBIA}

As an initial matter, it is important to distinguish cancerphobia claims from claims of increased risk of cancer. Recovery for increased risk of cancer rests solely on a claim that there is a heightened possibility of contracting cancer that can be measured with some degree of medical certainty. ${ }^{15}$ Plaintiffs allege future damages, including "future medical expenses, loss of earnings, [and] diminished life expectancy."16 In contrast, cancerphobia damages are "present damages for the serious emotional distress that [the plaintiff] already has suffered ... because of the substantial risk to the plaintiff's health posed by the defendant's negligence."17 Cancerphobia claims inherently entail a much larger subjective component than increased-risk-of-cancer claims: courts must ask not only whether the fear is actual, but also "whether a plaintiff's claimed distress is reasonable."18

Recovery for increased risk of cancer traditionally has been analyzed under a probabilistic standard of future damages that allows recovery only if the future consequences are "reasonably certain" to occur. ${ }^{19}$ Under this standard, reasonable certainty is defined as "more likely than not" or having a "probability of occurrence of greater than fifty percent." ${ }^{\text {"20 }}$ For example, in Abuan $v$ General Electric Co., plaintiffs who were allegedly exposed to PCBs brought a class action suit claiming increased risk of can-

15 Gale and Goyer, 35 Defense L J at 456 (cited in note 4); J. Joseph Reina, Recovery for Fear of Cancer and Increased Risk of Cancer: Problems with Gideon and a Proposed Solution, 7 Rev Litig 39, 50-51 (1987). See also Gideon v Johns-Manville Sales Corp., 761 F2d 1129, 1137-38 (5th Cir 1985) (holding that plaintiff can recover for increased risk of cancer only if there exists a reasonable medical probability that plaintiff will contract cancer). See also Comment, 29 Houston $L$ Rev at 240-41 (cited in note 5).

${ }^{16}$ Potter, 25 Cal Rptr 2d at 588 (George concurring in part and dissenting in part).

17 Id.

${ }^{18}$ Hennessy $v$ Commonwealth Edison Co., 764 F Supp 495, 504 (N D IIl 1991) (emphasis added).

${ }_{19}$ Gale and Goyer, 35 Defense L J at 456 (cited in note 4). This showing is often quite onerous and "[c]ourts have demonstrated [ ] resistance to the recognition of present recovery for increased risk of cancer due ... to medical science's present inability to quantify this risk." Id at 464.

${ }^{20}$ Id at 456. 
cer against the manufacturer of a ruptured electrical transformer. ${ }^{21}$ The Ninth Circuit upheld a finding of summary judgment for the defendant, as the plaintiffs did not meet their burden of showing that "the toxic exposure more probably than not will lead to the malady." 22 Recoveries for cancerphobia and other fears of disease, in contrast, have routinely been awarded with far less than a 50 percent probability showing. ${ }^{23}$

\section{The CurRent State of the LaW: Discussion and Critique}

This Part describes and critiques the various standards that courts have applied in evaluating cancerphobia claims. In fashioning tests to adjudicate cancerphobia suits, courts have generally been concerned with ensuring that claims are both genuine and reasonable; indeed, courts have developed a number of tests intended to screen out meritorious claims from overly speculative ones. Some courts require that a plaintiff suffer an injury either causing or resulting from the alleged fear. Other courts simply ask if the claimed fear is "reasonable," while still others require that the plaintiff prove she is likely to develop cancer before she can recover for her fear. These standards have all proved unsatisfactory in resolving cancerphobia suits.

\section{A. Physical Injury}

Many courts have held that, as a condition precedent to recovering for cancerphobia, a plaintiff must have a physical injury that caused her mental distress. ${ }^{24}$ Proponents of the physical injury requirement assert that this standard provides a "reasonable safeguard against false, trivial, evanescent, temporary, feigned, or imagined [claims]. ${ }^{\prime 25}$

\footnotetext{
213 F3d 329, 330 (9th Cir 1993).

${ }^{22}$ Id at 334. See also Sterling $v$ Velsicol, 855 F2d 1188, 1204 (6th Cir 1987); Cantrell $v$ GAF Corp, 999 F2d 1007 (6th Cir 1993).

${ }_{23}$ See, for example, Ferrara $v$ Galluchio, 5 NY2d 16, 176 NYS2d 996, 152 NE2d 249, 251,253 (1958) (fear that cancer might develop is sufficient even if actual medical likelihood is low); Wetherill $v$ University of Chicago, 565 F Supp 1553, 1559-60 (N D III 1983) (same); Heider v Employers Mutual Liability Insurance Co., 231 S2d 438, 442 (La App 1970) (damages recovered for fear of epilepsy upon a showing of 2 to 5 percent chance of future epilepsy).

24 See, for example, Wisniewski $v$ Johns-Manville Corp., 759 F2d 271, 274 (3d Cir 1985), aff'd, 812 F2d 81 (3d Cir 1987); Jackson v Johns-Manville Sales Corp., 781 F2d 394, 414 (5th Cir 1986); In re Hawaii Federal Asbestos Cases, 734 F Supp 1563, 1569 (D Hawaii 1990); Daley $v$ LaCroix, 384 Mich 4, 179 NW2d 390, 395 (1970); Fournell v Usher Pest Control Co., 208 Neb 684, 305 NW2d 605, 607 (1981).

${ }_{25}$ Payton v Abbott Labs, 386 Mass 540, 437 NE2d 171, 180 (1982). See also Hagerty $v$
} 
For example, in Jackson $v$ Johns-Manville Sales Corp., a former shipyard worker brought a cancerphobia suit against asbestos manufacturers. ${ }^{26}$ The court first noted that under Mississippi law, a plaintiff can recover for negligent infliction of mental distress only when his "mental suffering is accompanied by a physical injury." ${ }^{\text {"27 }}$ The court then upheld Jackson's cancerphobia recovery against the asbestos manufacturers, stating that the plaintiff's asbestosis was a "present physical injury" that fulfilled the physical injury requirement. ${ }^{28}$ In contrast, in Wisniewski $v$ Johns-Manville Corp., the wives and children of workers who died from asbestos exposure brought a cancerphobia action against asbestos manufacturers and vendors based on their fears of developing cancer from exposure to asbestos on the workers' clothing and tools. ${ }^{29}$ The court quickly disposed of the cancerphobia claim because the plaintiffs had "alleged no injuries that stem from exposure to the asbestos itself."

Demostrating a bodily injury is thus the core of the standard. Once the physical injury burden is satisfied, however, many courts seem to abandon entirely any requirement that plaintiffs show a correlation between the existing injury and future cancer. ${ }^{31}$ For example, the Jackson court blithely noted the defendant's argument that "there is no evidence that cancer 'develops from' asbestosis"; ${ }^{32}$ however, in its refusal to even indulge the assertion through analysis, the court indicated its belief that any causal nexus between the required injury and the future contraction of cancer is wholly irrelevant. ${ }^{33}$ In another case,

L \& L Marine Services, Inc., 788 F2d 315, 318 (5th Cir 1986) (stating that the objective harms standard "provide[s] courts with an objective means of ensuring that the alleged mental injury is not feigned"); Gale and Goyer, 35 Defense L J at 446 n 12 (cited in note 4).

26781 F2d 394, 413 (5th Cir 1986).

27 Id at 414 .

28 Id.

29759 F2d 271, 273 (3d Cir 1985).

30 Id at 274.

31 Dworkin, 53 Fordham L Rev at 544-45 (cited in note 11).

32781 F2d at 413 .

33 See also Eagle-Picher Industries, Inc. $v$ Cox, 481 S2d 517, 528 (Fla App 1985) (asbestosis satisfies physical impact requirement even though there is no medical evidence that asbestosis causes cancer); Herber $v$ Johns-Manville Corp., 785 F2d 79, 81, 85 (3d Cir 1986) (physical harm requirement satisfied by pleural thickening, a condition associated with exposure to asbestos, but not causally related to the development of cancer). But see Stites $v$ Sundstrand Heat Transfer, Inc., 660 F Supp 1516, 1522, 1526-27 (W D Mich 1987) (physical symptoms that are the result of anguish or fear are generally insufficient to constitute the requisite physical harm); Wisniewski, 759 F2d at 274 (headaches caused by fear of conracting cancer do not fulfill physical harm requirement; harm must have been 
Lorenc $v$ Chemirad Corp., the plaintiff, who had received a chemical burn on his hand, recovered for his fear of developing skin cancer even though it was extremely improbable that he would develop cancer and the cancer would have been fully preventable by a skin graft, which the plaintiff refused. ${ }^{34}$ In another fear-ofcancer case, the District Court of Appeal of Florida tried to explain why a link between the present injury and increased risk was not important:

[E]ven were it not shown that plaintiff's asbestosis in fact makes cancer more likely, his present asbestosis certainly provided him with a chronic, painful and concrete reminder that he has been injuriously exposed to a substantial amount of asbestos, a reminder which may both qualitatively and quantitatively intensify his fear. ${ }^{35}$

Assuming that a physical injury requirement should be retained in generic emotional distress claims, the requirement serves no function in cancerphobia claims, and instead confuses an already muddled jurisprudence. ${ }^{36}$ Reduced to its core, the physical harm requirement is intended to filter out frivolous claims by guaranteeing that only plaintiffs who have been seriously impaired will recover for emotional distress. However, this approach to cancerphobia claims fails on both fairness and efficiency grounds. Without requiring a nexus between the physical injury and an increased risk of cancer, the presence of a contemporaneous physical harm in cancerphobia claims generally has no bearing on whether a plaintiff is more likely to contract cancer, and thus on whether a given cancerphobia claim has more merit than another.

caused by asbestos itself). Courts have also mechanically applied the physical injury requirement in the absence of a probabilistic showing in nosophobia cases outside of the cancerphobia setting. See, for example, Heider v Employers Mutual Liability Insurance Co., 231 S2d 438 (La App 1970) (plaintiff recovered for fear of developing epilepsy after receiving cerebral concussion in car accident, despite fact that there was only a two to five percent chance of it actually developing). See also Dworkin, 53 Fordham L Rev at 544 (cited in note 11).

34 37 NJ 56, 179 A2d 401, 411-14 (1962) ('Although Dr. Lorenc's testimony as to the reasons for his failure to accept a skin graft is not very impressive, and although his reasons reflect adversely upon his fear of malignancy, and even upon the present need for such surgery," recovery should be upheld.).

${ }^{35}$ Eagle-Picher Industries, Inc. $v$ Cox, 481 S2d 517, 528 (Fla App 1985).

${ }^{35}$ Many have questioned whether the physical injury requirement is appropriate even in generic emotional distress claims. See Burgess v Superior Court, $2 \mathrm{Cal} 4$ th 1064, 9 Cal Rptr 2d 615, 619 (1992) ("damages for negligently inflicted emotional distress may be recovered in the absence of physical injury or impact"); Potter, 25 Cal Rptr $2 \mathrm{~d}$ at 563. 
Unless a nexus between the physical injury and future contraction of cancer is required, even a plaintiff's irrational fears would be countenanced as long as there existed some corroborating physical manifestation: fear of skin cancer from a defective razor would be authenticated by a shaving scar. Thus, the physical impact requirement utterly fails as an effective screening mechanism because it corroborates neither the genuineness nor the reasonableness of the fear. Indeed, all plaintiffs who are cognizant of their exposures to known carcinogens are equally likely to be fearful of contracting cancer, regardless of whether they have or have not developed an unrelated physical malady.

Requiring proof of physical injury is particularly problematic in the context of cancerphobia claims, where the underlying physical injury is the cancer that has yet to develop. This harm can almost never be shown, and requiring plaintiffs to wait until they contract cancer to bring their claims for fear of cancer means that their claims will not survive the statute of limitations, which runs from the time that the fear was initially generated. ${ }^{37}$ Fear thus must be presently compensable, but as the harm occurs before potential manifestation of the disease, almost any physical injury contemporaneous with the fear will, by definition, be irrelevant. As a result, retaining the physical harm requirement in cancerphobia actions serves only to confuse and distort cancerphobia claims. Although proponents of the physical harm requirement laud its fraud-preclusion function, the requirement actually encourages victims to:

exaggerate sick headaches, nausea, insomnia and other symptoms in order to make out a technical basis of bodily injury upon which to predicate a [.] recovery for the more grievous disturbance, consisting of the mental and emotional distress endured. ${ }^{38}$

${ }^{37}$ Indeed, some commentators have advocated eliminating precancer recoveries but tolling limitations periods until the plaintiff discovers, or should have discovered, the disease. See Reina, 7 Rev Litig at 58-59 (cited in note 15). Of course, since some cancers may not develop for many years after the tortious exposure, the negligent defendant may be defunct or insolvent at the time of discovery. Moreover, such an approach fails to compensate present fear, which may be extremely painful and serious in its own right. The question is thus one of establishing thresholds to ensure seriousness, and not one of eliminating fear as a cause of action.

${ }^{38}$ Potter, $25 \mathrm{Cal}$ Rptr 2d at 564. 
A physical injury requirement does little to stem the tide of cancerphobia claims when plaintiffs just have to make up physical maladies to get into the courthouse. ${ }^{39}$

In addition to its vulnerability to fraud, the rule's "bright line" is fatally blurred by its potential for overinclusion. Indeed, some courts have strained their creative faculties to find a requisite physical injury to meet this standard. One commentator, in arguing that "[t]he often-criticized 'impact rule' has been disarmed by judicial expansion," cites the example of a court which found impact under the rule because the plaintiff fainted and fell down after a collision. ${ }^{40}$

We are thus left with the argument that even if the physical injury requirement is arbitrary and can be evaded, it is singular in reducing what would otherwise be a massive influx of claims. Without such a gatekeeper, "the task of discerning fraudulent 'fear of' claims from meritorious ones would be 'prodigious."'41 However, as the Potter court made clear, the screen's imprecision is fatal; it is both over- and underinclusive. ${ }^{42}$ The seriousness of the exposure to a carcinogen and the legitimacy of cancerphobia claims can be gauged more effectively without requiring an accompanying physical injury. ${ }^{43}$

\section{B. Physical Manifestation of Cancerphobia}

Many courts, in a variation of the physical injury requirement, insist that plaintiffs' mental injuries manifest themselves in some physical injury before recovery will be allowed. For example, a plaintiff claiming mental distress would be required to show physical signs of the anguish-such as headaches, ulcers, or stress-before he or she could collect damages. ${ }^{44}$ Indeed, most courts require either an injury that caused the fear or physical manifestation of the fear as a condition precedent to recovery, ${ }^{45}$

39 As the court in Molien $v$ Kaiser Foundation Hospitals noted: "If physical injury, however slight, provides the ticket for admission to the courthouse, it is difficult for advocates of the ffloodgates' premonition to deny that the doors are already wide open." 27 Cal 3d 916, 167 Cal Rptr 831, 838 (1980). See also Comment, 29 Houston L Rev at 235238 (cited in note 5).

40 Gale and Goyer, 35 Defense $I J$ at $446-47$ (cited in note 4), referring to Comstock $v$ Wilson, 257 NY 231, 177 NE 431 (1931).

11 Eagle-Picher, 481 S2d at 529.

12 Potter, 25 Cal Rptr 2d at 564-65.

43 See Part III.

4 See, for example, Towns $v$ Anderson, 195 Colo 517, 579 P2d 1163, 1164 (1978); Barnhill v Davis, 300 NW2d 104, 106 (Iowa 1981). See also Payton v Abbott Labs, 386 Mass 540, 437 NE2d 171, 175 n 5 (1982) (listing cases on both sides of issue).

45 See Stites $v$ Sundstrand Heat Transfer, Inc., 660 F Supp 1516, 1526-27 (W D Mich 
and very few states follow only the physical injury rule. ${ }^{46}$ For purposes of conceptual clarity, however, the physical manifestation requirement will be discussed separately because it generates distinct analytic problems in the cancerphobia context.

Like the physical impact rule, the physical manifestation requirement evolved out of the continuing effort to circumscribe cancerphobia suits; "[i]t was assumed that if the distress were sufficient to cause physical injuries, the suits would not be frivolous or fraudulent and could be contained." ${ }^{37}$ In Stites $v$ Sundstrand Heat Transfer, Inc., residents brought a cancerphobia action against a manufacturer, alleging that their exposure to its chemicals caused them emotional distress in the form of cancerphobia. The court held that to recover for cancerphobia, plaintiffs must show "that they have suffered emotional distress as a proximate result of defendant's negligent conduct [and] that this emotional distress has manifested itself in definite and objective physical injury." ${ }^{\text {"48 }}$ The court in Payton $v$ Abbott Labs combined the physical impact/manifestation-of-the-distress requirements and simply held that "a plaintiff's physical harm must either cause or be caused by the emotional distress alleged, and ... must be manifested by objective symptomatology and substantiated by expert medical testimony. $\$ 49$

1987); Hennessy v Commonwealth Edison Co., 764 F Supp 495, 499-500 (N D Ill 1991); Payton, 437 NE2d at 181 (either physical injury or physical manifestation of distress satisfies physical injury requirement). For other cases requiring evidence of physical manifestation, see, for example, Daley $v$ LaCroix, 384 Mich 3, 79 NW2d 390, 395-96 (1970); Reilly $v$ United States, 547 A2d 894, 895 (RI 1988); Vance $v$ Vance, 286 Md 490, 408 A2d 728, 733-34 (1979); Hughes v Moore, 214 Va 27, 197 SE2d 214, 219 (1973); Dillon $v$ Legg, 68 Cal 2d 728, 69 Cal Rptr 72, 80 (1968); Mack v South Bound RR, 52 SC 323, 29 SE 905, 910 (1898).

${ }^{46}$ Dworkin, 53 Fordham $\mathrm{L}$ Rev at $550 \mathrm{n} 179$ (cited in note 11), citing William Winter, A Tort in Transition: Negligent Infliction of Mental Distress, ABA J 62, 64 (Mar 1984). Eight states still follow the impact rule: Arkansas, Florida, Georgia, Idaho, Indiana, Kentucky, Mississippi, and North Carolina. Winter, ABA J at 64.

47 Dworkin, 53 Fordham L Rev at 550 (cited in note 11). Many courts require physical manifestation of emotional distress in noncancerphobia claims as well. For example, the Supreme Court of Texas reinstituted the physical manifestation requirement in suits for negligent infliction of emotional distress in Boyles $v$ Kerr, a noncancerphobia case. 855 SW2d 593 (Tex 1993). In Boyles, the plaintiff brought suit after the defendant covertly videotaped the plaintiff having sex with the defendant, and then showed the videotape to his friends. In denying the plaintiff recovery without proof of physical manifestation of her emotional distress, the court stated that "the sole purpose of the physical manifestation rule is to ensure the genuineness of claims for emotional distress, and that physical manifestation is required in all situations except where "emotional distress is a recognized element of damages for breach of a legal duty." Id at 598.

43660 F Supp 1516, 1526 (W D Mich 1987).

4986 Mass 540, 437 NE2d 171, 181 (1982). 
Some courts that apply the physical manifestation requirement appear to be concerned with efficiency. For example, in Ayers $v$ Township of Jackson, the court applied a straight-laced physical manifestation requirement. ${ }^{50}$ The case involved a cancerphobia claim based on contamination of plaintiff's well water by the defendant's municipal landfill. In articulating its standard for evaluating the cancerphobia claim, the court stated:

In order for a claim of "cancerphobia" to be compensable, evidence must be presented to support a finding that emotional injury as evidenced by substantial bodily injury or sickness has resulted from knowledge that plaintiffs have ingested contaminants. Otherwise, the task of evaluating and quantifying each person's apprehension in every groundwater pollution case, each of which might involve hundreds, if not thousands of residents, would become prodigious. ${ }^{51}$

Like its cousin, physical injury, the manifestation-of-the-distress requirement is purported to serve as a cost-saving screen.

However, even in courts that clearly require a physical manifestation of the plaintiff's fear, the type or degree of manifestation that must be shown is not always defined. This uncertainty is exacerbated when coupled with the confusion which already pervades the cancerphobia arena. For example, in Laxton $v$ Orkin Exterminating Co., Inc., the Tennessee Supreme Court held that plaintiffs' consultation with medical personnel because of exposure to adulterated water constituted the requisite manifestation, even though the plaintiffs did not seek treatment for their cancerphobia or for any of its manifestations. ${ }^{52}$ In stark contrast to the majority of cancerphobia and other toxic tort plaintiffs, the Laxton plaintiffs' fear was relatively short lived, lasting only one month. ${ }^{53}$ Indeed, the Laxton precedent is somewhat unclear as to its dilution of the physical manifestation requirement. Many people exposed to toxins will seek the advice of a physician; if such consultation constitutes the requisite manifestation, then not only would the requirement lack rigor, but it would also con-

50 189 NJ Super 561, 461 A2d 184, 189 (1983), aff'd in part and rev'd in part, 106 NJ 557, 525 A2d 287 (1987).

iI Id. See also Gale and Goyer, 35 Defense L J at 453-54 (cited in note 4).

52 639 SW2d 431, 434 (Tenn 1982). See also Dworkin, 53 Fordham L Rev at 550-51 (cited in note 11).

*3 Comment, Sterling v. Velsicol Chemical Corp.: Emotional Distress Damages for the Duration of Toxic Exposure, 1989 Utah L Rev 759, 782. 
tain the road map for easy evasion..$^{54}$ Certainly, many courts will apply the manifestation requirement stringently and not render it semimeaningless, as did the Laxton court. ${ }^{55}$ However, the fact that the physical manifestation requirement contains the potential for such manipulation certainly undercuts its muchlauded efficacy as a rigorous screen for feigned emotional distress claims.

Requiring a physical manifestation of cancerphobia is as arbitrary as requiring an initial physical injury. Under the manifestation standard, a sufferer of cancerphobia in its medical sense-“as a 'phobic reaction,' [ ] a mental illness that is the recurrent experience of dread of a cancer in the absence of objective danger" ${ }^{256}$ - will be able to recover, but a cancerphobe who has a 95 percent chance of developing cancer, but has no physical manifestation of her cancerphobia, will not. Thus, the plaintiff's ability to collect for the fear of contracting cancer at a future date turns on the plaintiff's physiological idiosyncracies, rather than on whether his distress is genuine or reasonable. This requirement does not ensure that the cancerphobia is any more reasonable - only that it is genuine.

Moreover, this standard creates a perverse incentive structure that encourages plaintiffs to feign physical manifestations of cancerphobia. Indeed, because such manifestations necessarily encompass subjective symptoms, fabricated symptoms would often escape detection by objective medical examinations. As the Supreme Court of Texas stated in St. Elizabeth Hospital $v$ Garrard, which abandoned the physical manifestation requirement in actions for negligent infliction of emotional distress:

[T] he requirement is defective because it "encourages extravagant pleading and distorted testimony." ... "[I]n most instances of severe mental disturbance some deleterious physical consequence can, with a little ingenuity be found ..." and characterization of an injury as physical or mental may

54 Dworkin, 53 Fordham L Rev at 551-52 (cited in note 11).

ss Id. Dworkin makes clear that not all courts choose to follow Laxton in this regard. In Payton, for example, plaintiff's' medical exams, undergone on the advice of their doctors, were considered insufficient physical manifestations of their fear of cancer, and the court instead required "objective symptomatology of the physical manifestation and corroboration by expert medical testimony." Id at 552. See also Payton, 437 NE2d at 173-74, 181.

56 Potter, 25 Cal Rptr 2d at 559. See also Gale and Goyer, 35 Defense I J at 444-45 (cited in note 4). 
depend on the ingenuity of counsel in framing the pleadings. ${ }^{57}$

Application of the physical manifestation requirement to cancerphobia cases produces arbitrary outcomes and perverse incentives. The rule's gatekeeping function is easily ignored by any court willing to accept trivial physical manifestations as sufficient, and its attempt at clarity is thwarted by the absence of any standard as to what types of physical manifestation must be shown. The result is a rule that rewards strategic behavior and compensates true victims only by chance.

\section{Traditional "Reasonableness"}

A few courts have applied a traditional reasonableness standard to cancerphobia actions, holding that a plaintiff can recover for cancerphobia if a "normally constituted person" would experience the fear. ${ }^{58}$ These courts generally focus on compensating genuine and reasonable cancerphobes, and are less concerned with screening the mass flood of claims than are courts that apply the physical injury/manifestation-of-the-distress standards.

For example, Wetherill $v$ University of Chicago applied a traditional reasonability standard to the plaintiffs' fear-of-cancer claims. ${ }^{59}$ In Wetherill, plaintiffs who were exposed to DES in utero brought a cancerphobia action. The court stated that Illinois law did not recognize the physical injury standard, requiring instead physical impact "as distinct from injury," and that

57730 SW2d 649, 652-53 (Tex 1987) (quoting Molien v Kaiser Foundation Hospitals, 27 Cal 3d 916, 167 Cal Rptr 831, 838 (1980); Annotation, Right to Recover for Emotional Distur. bance or Its Physical Consequences, in the Absence of Impact or Other Actionable Wrong, 64 ALR2d 100, 117 n 18, 128 n 8 (1959)). In eliminating the physical manifestation requirement, the majority in St. Elizabeth stated that it was joining "an established trend in American jurisprudence which recognizes the tort of negligent infliction of mental anguish without imposing arbitrary restrictions on recovery in such actions." 730 SW2d at 654. Dissenting Justice Spears, however, argued for retaining the physical manifestation requirement, stating that "[s]even states, comprising a distinct minority, does not a trend make." Id at 655 .

St. Elizabeth overturned an earlier Texas Supreme Court opinion, Hill v Kimball, 76 Tex 210, 13 SW 59 (1890), which held that a plaintiff "probably" could not bring a cause of action for mental anguish apart from physical manifestation. Comment, 29 Houston $L$ Rev at 225-26 (cited in note 5). However, St. Elizabeth itself was overturned six years later in Boyles, 855 SW2d 593, which reinstituted the physical manifestation requirement in actions for negligent infliction of emotional distress.

${ }_{58}$ See, for example, Devlin $v$ Johns-Manville Corp., 202 NJ Super 556, 495 A2d 495, 497-98 (1985); Wetherill $v$ University of Chicago, 565 F Supp 1553, 1559 (N D II 1983); Hennessy $v$ Commonwealth Edison Co., 764 F Supp 495, 505 n 7 (N D Ill 1991).

565 F Supp 1553 (N D Il 1983). 
"[plaintiffs'] fears stem[med] from their prenatal exposure to DES - the 'physical impact' of defendants' allegedly tortious conduct." The court then made it clear that it was not basing its holding on physical injury or manifestation, but rather on a tra- . ditional reasonableness standard. The court struck down the defendant's argument that the plaintiff must demonstrate that her fear of cancer was grounded in "reasonable certainty"; instead, the court stated that "fears of future injury can be reasonable even where the likelihood of such injury is relatively low." The court thus articulated a standard of "reasonable fear" instead of requiring "a high degree of likelihood" that the plaintiff would actually develop cancer. ${ }^{62}$ The Wetherill court cited with approval Murphy v Penn Fruit Co. ${ }^{63}$ another traditional "reasonability" case, which upheld an award for "psychic injury" where the plaintiff feared cancer, heart attack, and premature death, even though such fears were "medically unfounded."

Similarly, Ferrara $v$ Galluchio held that a plaintiff merely needs to show that there is "a basis for her mental anxiety," that it is "plausible, under such circumstances, that plaintiff would undergo exceptional mental suffering over the possibility of developing cancer. ${ }^{165}$ Ferrara involved a plaintiff who went to a dermatologist for treatment of X-ray burns on her shoulder sustained while under the care of the defendants, doctors specializing in X-ray therapy. The dermatologist advised the plaintiff to have her shoulder examined every six months "inasmuch as the area of the burn might become cancerous." ${ }^{26}$ The case thus involved the unusual scenario of a subsequent doctor's advice causing the fear of cancer allegedly occasioned by the original doctors' negligent treatment. The plaintiff's lawyer stated at trial that "we are not making any claim that this person is going to sustain a cancer. We are going on a neurosis." ${ }^{\prime 67}$ In upholding recovery, the Ferrara court went out of its way to state that it was not creating a rule for cancerphobia recoveries, but was instead sim-

\footnotetext{
60 Id at 1560. The court's analysis demonstrates how specious a screen the physical impact requirement can be when applied by a creative judge.

61 Id at 1559. See also Hennessy, 764 F Supp at 505 n 7.

62565 F Supp at 1559.

$63274 \mathrm{~Pa}$ Super 427, 418 A2d 480 (1980).

64 565 F Supp at 1559 , citing Murphy, 418 A2d at $482,585$.

65 5 NY2d 16, 176 NYS 2d 996, 152 NE2d 249, 251, 253 (1958). See also Wetherill, 565 F Supp at 1559. Ferrara was also the first American case to use the term "cancerphobia." See Gale and Goyer, 35 Defense L J at 451 (cited in note 4).

66 152 NE2d at 251.

67 Id.
} 
ply following the dictates of pragmatism-"[i]t is common knowledge among laymen ... that wounds which do not heal over long periods of time frequently become cancerous.. ${ }^{168}$ Other courts, in rejecting physical injury/manifestation of distress, similarly embrace the commonsense intuitions of juries in their adherence to a reasonability standard. For example, in eliminating the physical manifestation requirement for all emotional distress claims, the Texas Supreme Court in St. Elizabeth boldly proclaimed:

The distinction between physical injury and emotional distress is no longer defensible. The problem is one of proof .... Jurors are best suited to determine whether and to what extent the defendant's conduct caused compensable mental anguish by referring to their own experience. ${ }^{69}$

In a different spin on the standard, some courts have attempted to infuse the reasonableness determination with more objectivity, but have ultimately failed to define a workable standard. For example, Hennessy $v$ Commonwealth Edison Co. involved a worker at a nuclear power station who was allegedly exposed to excessive radiation. ${ }^{70}$ The worker brought a cancerphobia suit even though the radiation to which he was exposed was relatively insignificant. Hennessy essentially "relie[d] on a claim of ignorance as the basis upon which his fear should be deemed reasonable." $\mathrm{He}$ claimed that because he was "not a health physicist," he "could not be expected to understand the relative insignificance of his internal exposure." 72 The court summarily dismissed such a wholly subjective notion of reasonableness, stating:

[A]bsent a basis in fact that would support Hennessy's fear that he either was or will be at risk for cancer ... such a belief founders on pure speculation, and hence cannot be said to be reasonable. ${ }^{73}$

${ }^{63}$ Id at 252. For a similar approach in a noncancerphobia case, see Heider $v$ Employers Mutual Liability Insurance Co., 231 S2d 438 (La App 1970), in which plaintiff recovered for fear of epilepsy despite medical experts' testimony that 'there was a $2 \%$ to $5 \%$ chance that one with injuries such as Mrs. Heider's would experience epileptic seizures in years to come." Id at 442 . See also Gale and Goyer, 35 Defense I J at 453 (cited in note 4).

๑7 730 sW2d at 654 .

764 F Supp 495 (N D Ill 1991).

11 Id at 505.

72 Id.

73 Id at 506. 
The court defined reasonability as simply a "tangible reason to believe [one] was actually endangered by the incident."74

The Iowa Court of Appeals also grounded its reasonability calculus in terms of objective probability in Kosmacek $v$ Farm Service Co-op of Persia. ${ }^{75}$ The plaintiffs in Kosmacek brought, among other actions, a cancerphobia suit against chemical companies who allegedly were negligent in allowing their carcinogenic chemicals to come onto the plaintiffs' property. In denying the requested relief, the court stated:

It is not enough for the plaintiffs to merely say they worried .... Rather, there must be reliable data available linking the particular herbicide the plaintiffs were exposed to to an increased future risk of development of cancer.

The court did not state how strong a showing the plaintiffs were required to make, only that as a condition precedent, the plaintiffs must make a showing that they "are aware they possess an increased statistical likelihood of developing cancer, and from this knowledge [ ] a reasonable apprehension which manifests itself in mental distress." B7 Both the Hennessy and Kosmacek courts, however, ultimately failed to give content to the reasonability/objectivity fault line by defining what the objective threshold is that must be crossed.

There are several problems in applying traditional reasonability tests to cancerphobia actions. First, as cases such as Wetherill and Ferrara convey, it might be quite reasonable for a given plaintiff to have a subjective fear of contracting cancer from a negligent exposure, even when she has only a negligible probability of actually developing the disease at a future date. This proposition, of course, presumes a definition of reasonableness as entailing what a reasonable member of society would fear. But this definition would clearly wreak havoc in the cancerphobia context, precisely because it is so reasonable to fear cancer. Indeed, "[i]t is difficult to go a week without news of toxic exposure ... [and a] member of our society faces a one in five chance of develóping cancer." ${ }^{38}$ Potential plaintiffs' classes in cancerphobia actions could be enormous ${ }^{79}$ under any standard, and their

74 Id.

75485 NW2d 99 (Iowa App 1992).

76 Id at 104.

77 Id at 105.

${ }_{78}$ Dworkin, 53 Fordham L Rev at 576 (cited in note 11). See also Potter, 25 Cal Rptr $2 \mathrm{~d}$ at 566-67.

79 Potter, 25 Cal Rptr 2d at 566-67. See also Robert I. Willmore, In Fear of Cancer- 
size would certainly be augmented if courts adopted a traditional definition of reasonableness (as used by Wetherill and Ferrana, which ask, "What would the reasonable member of society fear?"). Second, large cancerphobia awards would give potential defendants an incentive to conceal information about the release of carcinogens, rather than rapidly disclosing such information, because the release of such information could spawn "reasonable" cancerphobia claims. Polluters would also be less likely to carry insurance, as large-scale cancerphobia recoveries would in all likelihood substantially increase insurance premiums. ${ }^{80}$ As a result, people would actually be at a greater risk of unknowing exposure to carcinogens and would be less likely to receive compensation for their genuine and reasonable fear.

Moreover, unbounded cancerphobia awards together with the increased cost of insuring against cancerphobia liability "could diminish the availability of new, beneficial prescription drugs or increase their price beyond the reach of those who need them most," ${ }^{\prime 81}$ as prescription drug manufacturers would be particularly hard hit by a regime that permitted relatively unbounded cancerphobia recoveries. By encouraging jurors to implement their own subjective intuitions in fashioning recoveries, no check at all is placed on the flood of aforementioned public policy nightmares. Moreover, courts such as the one in St. Elizabeth, which dispensed with the physical manifestation requirement, are prone to falling into this traditional reasonability abyss as a default standard if they do not define any replacement test. Indeed, as one commentator noted, "St. Elizabeth can easily constitute the completion of the work begun in Hill: the recognition of negligent infliction of mental anguish as a valid claim simply requiring proof of duty, breach, causation, and injury." ${ }^{\prime 2}$ By removing the physical manifestation screen, the St. Elizabeth court thus instituted a de facto negligence/reasonableness regime-a portentious development in cancerphobia jurisprudence. Indeed, as the Texas Supreme Court recently stated in Boyles $v$ Kerr, which overruled St. Elizabeth (and ironically reinstituted the even less workable physical manifestation requirement), "It is difficult to imagine how a set of rules could be developed and

phobia, 56 Def Couns J 50, 55-56 (1989).

so Potter, 25 Cal Rptr 2d at 567.

i1 Id at 568 .

$\&$ Comment, 29 Houston L Rev at 235 (cited in note 5). 
applied on a case-by-case basis to distinguish severe from nonsevere emotional harm." ${ }^{\prime 33}$

Although cases such as Hennessy and Kosmacek attempt to break the traditional reasonableness paradigm by introducing some notion of probability, they do not indicate exactly how great this increased probability must be. Kosmacek refers only to an "increased statistical likelihood of developing cancer." Because the probabilistic increase at which fears become genuine is not specified, the Kosmacek test does not adequately address the genuineness concern in cancerphobia suits. Although genuineness of fear of cancer may be presumed at a 40 percent chance of developing cancer, it probably cannot be presumed with a 1 percent chance, which itself might still be twice the level of general exposure. Because no specification is given to juries as to how great the increase in probability must be, under Kosmacek's standard they most likely will revert to their subjective intuitions in fashioning recoveries.

\section{The "More Likely than Not" Objective Probability Test}

A minority of courts has moved away from the physical impact, physical manifestation, and traditional reasonableness notions, and has instead followed an objective probability analysis. These courts require the plaintiff to show proof that it is more likely than not, or greater than a 50 percent chance, that he will develop cancer as a result of the defendant's actions. ${ }^{85}$

For example, in Potter $v$ Firestone Tire \& Rubber Co., the Supreme Court of California applied a more-likely-than-not objective probability standard and explicitly rejected the physical impact requirement in cancerphobia actions. ${ }^{86}$ In Potter, the plaintiffs brought suit after learning that toxic chemicals, released by the defendant, had contaminated their well water. The court rejected the California Court of Appeal's holding that permitted recovery even though the plaintiffs were not able to show that it was likely that they would develop cancer. ${ }^{87}$ The court

83855 SW2d 593, 600 (Tex 1993), quoting Richard N. Pearson, Liability to Bystanders for Negligently Inflicted Emotional Harm-A Comment on the Nature of Arbitrary Rules, 34 U Fla L Rev 477, 511 (1982).

84485 NW2d at 105.

85 See Potter, 25 Cal Rptr 2d at 571; Gideon v Johns-Mansville Sales Corp., 761 F2d 1129, 1137-38 (5th Cir 1985).

$25 \mathrm{Cal}$ Rptr $2 \mathrm{~d}$ at 571.

${ }^{87}$ The Court of Appeal's holding is recorded in Potter v Firestone Tire \& Rubber Co., 232 Cal App 3d 1114, 274 Cal Rptr 885, 892 (1990). 
first agreed with the appellate court that the physical injury requirement should be abandoned in cancerphobia actions, stating that although limits on the number of potential cancerphobia plaintiffs and clear rules are desirable, "imposing a physical injury requirement represents an inherently flawed and inferior means of attempting to achieve these goals." announced its new standard for cancerphobia cases: the plaintiff must show that her likelihood of contracting cancer exceeds 50 percent. In explaining why it chose a more-likely-than-not standard, the court stated:

[Although] we would be very hard pressed to find that, as a matter of law, a plaintiff faced with a 20 percent or 30 percent chance of developing cancer cannot genuinely, seriously and reasonably fear the prospect of cancer[,] ... we conclude, for [ ] public policy reasons . . . that emotional distress caused by the fear of a cancer that is not probable should [ ] not be compensable. ${ }^{89}$

Among the public policy reasons the court listed as militating against large-scale cancerphobia awards, and hence in favor of the restrictive more-likely-than-not standard, are widespread public exposure to carcinogens, virtually unlimited potential plaintiffs' classes, potential large increases in the cost of liability insurance, possible reductions in the availability of new prescription drugs, ensuring recovery to those victims who ultimately will develop cancer, and establishing a predictable cutoff for recovery to provide for consistent case-to-case application..$^{90}$

It is not apparent from the cases why these courts chose 50 percent as their cutoff point for recovery. Certainly the hypothetical mass plaintiffs who cause public policy worries cannot make 30 or 40 percent probability showings. It appears that the Potter court wanted to make a clear demarcation line at the 50 percent mark simply for the purpose of making a clear cutoff point. However, as dissenting Justice George noted:

[A] reasonable person who has consumed, cooked with, and bathed in water that has been contaminated by toxic waste is likely to sustain serious emotional distress relating to the fear of developing a serious illness in the future, not only

\footnotetext{
89 Potter, 25 Cal Rptr 2d at 565.

(2) Id 566 .

so Id at 566-69.
} 
when the person's chance of developing an illness is more than 50 percent, but also when his or her chance of developing the illness is considerably lower, for example, "only" 25 or 30 percent. ${ }^{91}$

The more-likely-than-not approach affords no protection to such claimants.

Moreover, the more-likely-than-not approach confuses recovery for fear of cancer with recovery for increased risk of cancer, and vitimately merges both causes of action into one test. The standard for increased-risk-of-cancer claims has traditionally been whether the plaintiff can show a greater than 50 percent chance of contracting the disease in the future. ${ }^{92}$ Such an approach seems sensible because the recovery is for future damages. Cancerphobia, however, is a present harm, and thus the more-likely-than-not test seems misguided in this setting. As Justice George argued in his dissent in Potter, it makes little sense to distinguish between the cancerphobe who can make a 49 percent showing versus one who can make a 51 percent showing- " $t]$ he 'more-likely-than-not' test is used to determine whether to compensate for the future consequence itself; not for the present fear of such a future consequence. ${ }^{\prime 93}$ Under this standard, any plaintiff who recovers for fear of cancer should also recover for increased risk of cancer. Yet, if the same standard is used for evaluating both fear of cancer and increased-risk-ofcancer claims, plaintiffs with substantial exposure to carcinogens and genuine fears based on tangible facts will often receive no compensation for their cancerphobia claims merely because they have less than a 50 percent chance of contracting cancer. The Potter court's conflation of these two standards fails to define and quantify fear as a distinct, compensable injury with repercussions far more immediate and certain than increased-risk-of-cancer claims. It automatically compensates increased-risk-of-cancer plaintiffs for cancerphobia while leaving many meritorious fear claims uncompensated.

91 Id at 587 (George concurring in part and dissenting in part).

${ }_{92}$ Id at 592 (George concurring in part and dissenting in part). See also Gideon, 761 F2d at 1137-38.

${ }^{93} 25 \mathrm{Cal}$ Rptr 2d at 565 (George concurring in part and dissenting in part), quoting from Edward J. Schwartzbauer and Sidney Shindell, Cancer and the Adjudicative Process: The Interface of Environmental Protection and Toxic Tort Law, 14 Am J L \& Med 1, 43 (1988). 


\section{Proposal: The Substantial Probability Approach}

The divergent standards that courts have adopted in attempting to sort through cancerphobia actions are, in part, attributable to the general confusion that imbues the jurisprudence of emotional distress damages. ${ }^{94}$ Although the physical harm requirement fails both as an indicator of the likelihood of a cancerphobe contracting cancer and as a gatekeeper that ensures that only genuine cancerphobia claims will survive, there still are compelling policy reasons for strictly limiting cancerphobia claims. These reasons strongly militate against adopting a traditional reasonableness requirement in cancerphobia actions. First, "all of us are exposed to carcinogens every day. . . . Although few are exposed to all, few also can escape exposure to any. ${ }^{95}$ Potential plaintiffs' classes in cancerphobia actions may be enormous. ${ }^{96}$ Indeed, the numbers are daunting in the asbestos arena alone. One study found that roughly $\mathbf{1 4 . 1}$ million workers have been significantly exposed to asbestos since $1940 .{ }^{97}$ Moreover, as noted above, large cancerphobia awards might give potential defendants an incentive to conceal information about the release of carcinogens and make polluters less likely to carry insurance. ${ }^{98}$ Unbounded cancerphobia awards could also make beneficial prescription drugs less available or too expensive for the people who need them most. ${ }^{99}$

For these reasons, a screening mechanism is clearly warranted in cancerphobia actions, and the Potter court properly focused on objective probability as an appropriate gatekeeper..$^{100}$ However, the court created a needlessly harsh "more-likely-than-not" standard that frustrates meritorious suits. It also conflated the increased-risk-of-cancer test with a normative test for fear of can-

\footnotetext{
${ }^{34}$ See Dworkin, 53 Fordham L Rev at 528-31 (cited in note 11); Gale and Goyer, 35 Defense $\mathrm{L} J$ at $445-49$ (cited in note 4).

${ }_{95}$ Potter, $25 \mathrm{Cal}$ Rptr 2d at 566-67, quoting in part from Dworkin, 53 Fordham L Rev at 576 (cited in note 11).

${ }_{90}$ Potter, 25 Cal Rptr 2d at 567. See also Willmore, 56 Def Couns J at 55-56 (cited in note 79).

97 Dworkin, 53 Fordham L Rev at 562 (cited in note 11).

${ }_{93}$ Potter, 25 Cal Rptr $2 \mathrm{~d}$ at 567.

Is Id at 568 .

${ }_{100}$ The majority, in dispensing with the traditional reasonableness requirement, stated:
}

[T] ]he way to avoid damage awards for unreasonable fear, i.e., in those cases where the feared cancer is at best only remotely possible, is to require a showing of the actual likelihood of the feared cancer to establish its significance.

Id at 566. Of course, the majority required that the showing exceed 50 percent. Id at 571. 
cer, and ignored the fact that the harm of cancerphobia is more immediate and certain than the possibility of developing cancer in the future. Hence, some middle-ground solution is warranted in cancerphobia suits. Indeed, in this setting it is critical to identify "compromise solutions in an effort to satisfy the very real concerns which arise when plaintiffs realize that they have been exposed to carcinogens." 101 Moreover, the vast numbers of people and sums of money at stake make a clear standard desirable. The case is thus presented for adopting a substantial probability test, rather than the more-likely-than-not, physical injury, physical manifestation, or traditional reasonability tests. ${ }^{102}$ Reasonableness should be redefined in terms of probability.

Assume a plaintiff has lived in an asbestos-contaminated building her entire life and genuinely fears cancer when she learns of the contamination. Assume further that her actual chances of contracting cancer are only slightly higher than those of the general population. If reasonableness is defined in terms of the "reasonably constituted person," she may be said to reasonably fear cancer, even if her chances of contracting cancer are very low. In an ironic sense, someone in our plaintiff's position could reasonably harbor fears that are unreasonable in the sense that they have a very low statistical probability of materializing. ${ }^{103}$ However, if reasonableness is defined in terms of sub-

101 Comment, 29 Houston I Rev at 232-33 (cited in note 5). See also Dworkin, 53 Fordham L Rev at 565 (cited in note 11). Dworkin discusses possible effects of fear of cancer such as "mild depression to severe psychosis ... stress, outbursts of rage and hostility, [and] loss of sleep." Id.

102 In his dissent in Potter, Justice George essentially proposed such a test, perhaps based on the Court of Appeal's formulation, stating that prior to recovery, a plaintiff must establish not only the defendant's negligence, but also that:

the level of toxic substances to which he or she was exposed posed a significant risk that the plaintiff will develop the feared disease or illness (i.e., a risk that is sufficiently substantial that it would result in serious emotional distress in a reasonable... person).

25 Cal Rptr 2d at 591 (George concurring in part and dissenting in part). George does not outline the standard further, and his dissent focuses on attacking the more-likely-than-not approach adopted by the majority.

The Potter majority also characterized the Court of Appeal as following this approach, stating that the court erred in concluding that reasonableness is established by the mere fact of an exposure or a significant increase in the risk of cancer." 25 Cal Rptr 2d at 565-66. See also Potter v Firestone Tire \& Rubber Co., 232 Cal App 3d 1114, 274 Cal Rptr 885, 893 (1990) ("[I]n determining whether the circumstances are such to cause serious emotional distress in a reasonable person, the factfinder should consider evidence regarding the likelihood that the cancer will occur.").

${ }_{103}$ For holdings that plaintiffs in this situation can recover for cancerphobia, absent either a physical injury/manifestation or any probabilistic showing, see Devlin $v$ Johns- 
stantial probability, it would plainly appear unreasonable to fear a .5 percent increased chance of contracting cancer over the societal rate based on general levels of exposure. ${ }^{104}$ In terms of harder cases, where the plaintiff suffers, for example, an 8 percent increase over general levels of exposure, it seems appropriate that the jury decide whether the probabilistic increase is substantial enough to make the plaintiff's fear reasonable (and not whether a reasonable person in the plaintiff's position would experience fear, regardless of the probability of future cancer contraction). Indeed, as Justice George argued in his dissent in Potter, the substantial probability test "is sufficiently intelligible to any layman to furnish an adequate guide to the jury, and it is neither possible nor desirable to reduce it to lower terms. ${ }^{105}$

Such a standard would screen out virtually as many claims as the Potter more-likely-than-not standard, but would not arbitrarily cut off the plaintiff who can show a 30 percent chance of developing cancer, or even a 47 percent chance, but not a 51 percent chance. Because the marginal cases are not the voluminous ones that generate the pressing policy concerns, it seems inequitable to cut them off by adopting an overly harsh standard when a "substantial probability" test would bring the screening benefits without harsh or unfair results.

The substantial probability test would screen out more frivolous claims (indeed, no frivolous claims should survive the test) than the purportedly strict physical impact test without ushering in any of the public policy nightmares about which courts and commentators have worried in the cancerphobia setting. Whereas impact (either initial injury or manifestation of the distress) will frequently be either trivial or even feigned, and will often lack any correlation with future chances of developing cancer, the substantial probability test precludes triviality, fraud, and irrelevance. Substantial probability adequately addresses both the genuineness and the reasonability of the fear in one test-if a substantial probability showing can be made, genuineness will be

\footnotetext{
Manville Corp., 202 NJ Super 556, 495 A2d 495, 499 (1985); Laxton, 639 SW2d at 434.

${ }^{104}$ See Potter, 25 Cal Rptr at 566 ("[A] plaintiff's risk of contracting cancer might be significantly increased by 100 or more percent due to a particular toxic exposure, yet the actual risk of the feared cancer might itself be insignificant and no more than a mere possibility.").

${ }^{105}$ Id at 591 (George concurring in part and dissenting in part), quoting Mitchell $v$ Gonzales, 54 Cal 3d 1041, 1 Cal Rptr 2d 913, 919-20 (1991). Justice George also notes that "we have affirmed the reliability of the 'substantial' factor test as a means of ... delimiting liability in other contexts of tort law." 25 Cal Rptr 2d at 591 (George concurring in part and dissenting in part).
} 
presumed. Hence, the test represents a conceptual clarification over the physical impact and traditional reasonability tests without cutting as needlessly deep as the more-likely-than-not standard, which excludes meritorious suits and merges cancerphobia into increased-risk-of-cancer claims.

To illustrate this approach, it is instructive to consider a relatively meritless cancerphobia suit, and compare its results under the various standards. Rittenhouse $v$ St. Regis Hotel Joint Venture involved a plaintiff who sued the St. Regis Hotel in New York City for "mental anguish" caused by alleged exposure to asbestos while the plaintiff was a guest at the hotel. ${ }^{106}$ The court dismissed the entire complaint on the ground that no rational basis existed for the plaintiff's fear because "all objective testing of plaintiff's person and possessions have demonstrated no physical manifestation of an asbestos-related condition."107 Indeed, the plaintiff in Rittenhouse presented no evidence that she was ever exposed to asbestos at all. ${ }^{108}$ Although the court alluded to the lack of a physical injury as at least partially dispositive to its holding, there was no reason to do so. The court itself stated that:

A reasonable person ... should know that of those exposed to asbestos, only a small percentage suffer from asbestosrelated physical impairment and of that impairment group fewer still develop [recognizable diseases]. ${ }^{109}$

Even with a showing of asbestosis, a cancerphobia claim would be statistically unreasonable. However, if the Rittenhouse plaintiff had developed "night sweats" due to her fears of cancer, or had suffered a sprained ankle in her attempt to flee the hotel after learning of the asbestos contamination, neither the physical injury nor the physical-manifestation-of-the-distress requirements would preclude her recovery; the "screen" would thus be quite porous. In contrast, the substantial probability standard would provide an effective screen grounded in relevance and equity.

The Potter more-likely-than-not standard, although also screening out this claim, would provide too deep a cut. What if

106149 Misc 2d 452, 565 NYS2d 365, 366 (Sup Ct 1990), aff'd in part and rev'd in part, 180 AD2d 523, 579 NYS2d 100 (1992).

107565 NYS2d at 367-68.

109 Id.

109 Id at 367, quoting In re Hawaii Federal Asbestos Cases, 734 F Supp 1563, 1570 (D Hawaii 1990). 
the plaintiff in Rittenhouse could demonstrate a 40 percent chance of contracting cancer ${ }^{110}$ and did not have a contemporaneous, but irrelevant, accompanying malady? The substantial probability standard would be the only one that would compensate the victim for her statistically reasonable fear of contracting cancer. As this case would be well above the levels of general exposure, and thus differentiated from the cases which would wreak havoc on public policy, there is no reason to screen it out using either the physical harm or more-likely-than-not standard.

\section{CONCLUSION}

Cancerphobia suits have become increasingly prevalent in recent years. A confused jurisprudence has emerged along with this propagation. Because of the numbers of people and amounts of money involved in such suits, and their potential impact on the legal and health care'systems, it is critical to establish a guiding standard for cancerphobia actions, one that preserves equity while maintaining efficiency by allowing only a manageable degree of meritorious suits to go forward.

This Comment outlines a rule, substantial probability, which would allow plaintiffs to recover for their fear of cancer only if they can prove that they have a substantial probability of developing cancer at a future date. This rule is more rigorous and difficult to recover under than the traditional reasonableness standard, but it is also less arbitrary and offers a more effective screen than the physical injury/manifestation requirement that many courts apply. It is more equitable, less arbitrary, and less confusing conceptually than the more-likely-than-not rule, and still remains an effective screening mechanism.

110 This showing, itself, would be quite an onerous burden, far beyond the ability of an average guest at an asbestos-contaminated hotel. 
$$
\text { . }
$$ 